\title{
Algumas lições sobre o valor da ciência a partir do fenômeno da pós-verdade*
}

\author{
What we can learn about the value of science from \\ an review on the post-truth phenomenon
}

\author{
Prof. Dr. Leonardo Rogério \\ Miguel \\ Universidade Estadual do \\ Norte Fluminense Darcy \\ Ribeiro - UENF \\ e-mail: 1rmiguel@uenf.br

\section{ORCID} \\ https://orcid.org/0000-0003- \\ 2463-6321
}

Caroline Garcia Gonçalves Graduanda UFF Campos dos Goytacazes

e-mail: carolinegg@id.uff.br

\section{ORCID}

https://orcid.org/0000-0002$\underline{7080-7104}$

Recebido em: 10/04/2021

Aceito em: 11/10/2021

* Os autores agradecem as contribuições de Antonio Augusto Passos Videira (UERJ), Vinícius Carvalho de Silva (UFMS) e Clara da Cruz Vidart Badia (PPGBOT-UFV) durante o processo de realização deste trabalho.

\section{Resumo}

Trata-se de um exame de produções intelectuais relevantes para a compreensão do fenômeno da pós-verdade e dos desafios que impõe sobre valores e virtudes relacionados ao pensamento e à prática científica. $\mathrm{O}$ objetivo central é apresentar abordagens diversificadas para encaminhar uma reflexão sobre alguns problemas de cunho político, filosófico e psicológico suscitados pelas características e consequências de tal fenômeno, bem como pelos fatores que promovem. A partir da definição padrão e de uma definição alternativa para a pós-verdade, defendemos que a atenção aos vieses cognitivos, as teorias da verdade e as atitudes filosófico-científicas seja estratégia imprescindível para lidar com a "metonímia de nossos tempos" de forma intelectual e politicamente responsável.

Palavras-chaves: Pós-verdade, Teorias da Verdade; Valores científicos; Psicologia cognitiva; Negação da ciência.

\section{Abstract}

This is a review of selected researches on post-truth phenomenon in order to understand the challenges it imposes. Our aim is to present a variety of approaches on political, philosophical and psychological issues raised by the characteristics, factor and outcomes of such phenomenon. Based on the standard definition of post-truth and on an alternative version for this, we argue that being aware of our cognitive biases, assessing the theory of truth assumed by popular post-truth approaches, and adopting philosophical-scientific attitudes are proper ways to deal with the so-called "post-truth age" in scientific education and beyond.

Keywords: Post-truth; Theories of truth; Cognitive Psichology; Scientific denialism 


\section{Introdução}

O Oxford Dictionaries escolheu "pós-verdade" como a palavra internacional do ano de 2016. O título concedido se justifica pelo significativo crescimento do uso da palavra naquele ano: um aumento de $2000 \%$ em comparação ao ano de 2015 (SANTAELLA, 2019, p.17). Daí em diante, tendo em vista que se apresentam como ponto de partida de livros, artigos e notícias sobre o assunto (especialmente a partir de 2017), tornou-se lugar-comum introduzir um escrito relativo ao fenômeno da pós-verdade citando a definição registrada no referido dicionário, a saber: "um termo relativo às circunstâncias, ou que denota circunstâncias nas quais apelos à emoção e à crença pessoal são mais influentes do que os fatos objetivos na conformação da opinião pública" (tradução livre) ${ }^{1}$.

A fim de contribuir com as discussões sobre o tema do presente dossiê, realizamos uma exposição comentada de produções intelectuais que consideramos relevantes para a análise daquela definição e de suas possíveis implicações para a compreensão do papel dos valores na ciência e o próprio valor da atividade científica como uma fonte de expressões e estímulos para a responsabilidade epistêmica. O objetivo central é apresentar abordagens diversificadas para encaminhar uma reflexão sobre alguns problemas de cunho filosófico, político e psicológico que o fenômeno da pós-verdade impõe sobre os envolvidos com a pesquisa e a educação científicas. Nos referimos, em especial, àqueles profissionais que lidam tanto com alunos dos Ensinos Fundamental e Médio, quanto de graduações em qualquer área de conhecimento e com o público em geral.

Decerto, não temos a intenção de pautar o modo como cientistas, professores e educadores científicos deveriam lidar com a pós-verdade em seus tratos com o público leigo e em suas aulas, principalmente em virtude das especificidades da divulgação e ensino de ciências e da complexidade do tema proposto sobre valores da ciência. Contudo, esperamos que o nosso trabalho seja uma contribuição interessante e, talvez, útil para as controvérsias relativas à pós-verdade que, por ventura, ocorram em sala de aula e em discussões públicas. Assim sendo, ao tratarmos de implicações da pós-verdade nos contextos supramencionados, estamos tão-somente levantando ponderações e sugestões a partir das abordagens dos autores selecionados - contexto do problema, suas manifestações e suas nuances, os fatores que o promovem, suas consequências, etc. -, tanto os que se dedicam especificamente ao tema da pós-verdade, quanto aos que recorremos apenas para complementar e/ou lançar algum contraponto relevante.

Acima, afirmamos o uso de "abordagens diversificadas". Isto quer dizer que, para nossos fins e em vista do público que tentamos alcançar, não estabelecemos níveis de relevância acadêmica entre as referências bibliográficas. Todos os livros, artigos, materiais jornalísticos e fontes extraídos da internet são explorados com a mesma seriedade e apresentados quando consideramos apropriado para a composição de nossa exposição e argumentação.

O desenvolvimento do texto se estrutura em quatro seções divididas em subseções. Na primeira, são descritas as origens do neologismo "pós-verdade" e os motivos que levaram à massificação de seu uso no contexto político; na segunda seção, mostramos alguns modos como a "pós-verdade está em nós", bem como apresentamos nossa defesa sobre a atenção aos vieses cognitivos e suas implicações. A terceira seção é dedicada a um artigo que investiga o conceito de "verdade" pressuposto na definição padrão da pós-verdade. Ao final desse exame, também apresentamos, brevemente, as implicações de uma "filosofia da pós-verdade" para o ensino e a divulgação científica. Concluímos com as principais considerações deste trabalho.

\section{Origens: mentira, manipulação e complacência}

Um dos critérios para o coroamento e para a definição da pós-verdade em 2016 foi a capacidade de a palavra captar o "ethos, o humor e as preocupações [daquele] ano em particular e de ter duradouro potencial

1 https: //em.oxforddictionaries.com/definiton/post-truth. Grifos nossos. 
como uma palavra de significância cultural"2. Como é sabido, em junho de 2016, ocorreu o referendo sobre o Brexit (processo de saída da Reino Unido da União Europeia); em julho, houve novo pico no uso da palavra graças à escolha de Donald Trump como candidato do Partido Republicano à presidência dos EUA. O termo despontou com as repercussões das estratégias de marketing político, com especial referência às campanhas do Brexit e à eleição nos EUA, que foi marcada pelo "livre fluxo" de distorções da realidade e de acusações de mentiras (fake news) entre os então candidatos Trump e a democrata Hilary Clinton. Contudo, a seleção da palavra se deu antes do resultado do pleito, em virtude de seu uso para caracterizar as arraigadas discussões políticas e sociais, incrementadas pela ascensão das redes sociais digitais como fontes de notícias e propagandas políticas para grupos específicos (as "bolhas filtradas"3), o descrédito e a manipulação dos fatos pelos próprios representantes da política e das mídias (tradicionais e alternativas) ${ }^{4}$.

Embora o célebre neologismo tenha captado o "espírito de 2016", as circunstâncias que denota já haviam sido detectadas e classificas anos antes. A expressão "mundo da pós-verdade" aparece pela primeira vez no artigo "Um governo de mentiras" (publicado na revista norte-americana The Nation) em 1992. O autor do artigo é o dramaturgo sérvio-norte-americano Steve Tesich ${ }^{5}$ (1942-1996). Em 2004, dando os créditos a Tesich, o escritor Ralph Keyes publica "A Era da Pós-verdade: desonestidade e enganação na vida contemporânea"6. No ano de 2010, um blogueiro chamado David Roberts cunhou a expressão "política da pós-verdade" (BUCCI, 2018, p.21; D’ANCONA, 2018, p. 21)7. De modo geral, as expressões criadas por esses autores nos dizem que vivemos em um "mundo" ou em um "tempo" em que a verdade é irrelevante (BRAHMS, 2019; SANTAELLA, 2019 , p. 49) para os modos como lidamos com o poder, nos organizamos e nos relacionamos socialmente.

Dois meses antes da escolha do Dicionário Oxford, a chamada da capa da edição de 10 de setembro do tradicional semanário britânico The Economist resumiu de forma pertinente o "ethos, o humor e as preocupações" do ano de 2016, assim como a "significância cultural" da palavra "pós-verdade": "Arte das mentiras: A política da pós-verdade na Era das redes sociais" (SANTAELLA, 2019, p.47). Segundo Matthew D’Ancona, há mais do que isso. Para o jornalista britânico, a força de ascensão da pós-verdade foi o comportamento dos cidadãos, que recompensaram com sucesso político os homens e mulheres que mentem (D’ANCONA, 2018, p.60): "[As] mentiras, as manipulações e as falsidades políticas enfaticamente não são o mesmo que a pós-verdade. A novidade não é a desonestidade dos políticos, mas a resposta do público a isso. A indignação dá lugar à indiferença e, por fim, à conivência" (Ibid, p. 34. Grifos nossos).

Em resumo, políticos corriqueiramente distorcem a realidade, mentem e manipulam (com ajuda dos Relações Públicas) a opinião pública ${ }^{8}$. O problema está no aumento do nível de tolerância, complacência, impunidade e, não raro, inconsciência em relação às tais práticas desonestas. De 1992 a 2016 (e atualmente, aliás), a novidade também se encontra nos avanços das tecnologias de comunicação que geraram a referida "Era das redes sociais" da internet, que transformou nossas vidas sociais em um campo de batalha repleto de

2 Katherine Martin, chefe dos dicionários no EUA para a Oxford University Press. https://www.washingtonpost.com/news/the-fix/wp/2016/11/16/post-truth-named-2016-word-of-the-year-by-oxford-dictionaries/ Recuperado em 20 de maio de 2020 Cf. SANTAELLA, 2019, pp. 13-24.

4 Cf. "Os engenheiros do caos" (2020), de Giuliano Da Empoli, para uma rica narrativa acerca de como foram concebidas as influências de "bolhas sociais" da Internet, das fake news, das teorias da conspiração e dos algoritmos sobre os resultados das eleições na Europa, nos EUA e no Brasil nos últimos 15 anos, aproximadamente, assim como o uso daqueles recursos para disseminar medo e ódio nos eleitores.

5 TESICH, S. A government of lies, 1992. Disponível em: https://www.thefreelibrary.com/A+government+of+lies.-a011665982. Cf. D’ANCONA, 2018, p. 21; BRAHMS, 2019; SANTAELLA, 2019, p.48.

6 "A pós-veracidade existe em uma zona ética crepuscular. Permite-nos dissimularmos sem nos considerarmos desonestos. Quando o nosso comportamento entra em conflito com os nossos valores, o que somos mais propensos a fazer é reconceber os nossos valores. Poucos de nós queremos pensar em nós mesmos como sendo antiéticos, muito menos admitir isso para os outros, de modo que desenvolvemos abordagens alternativas da moralidade". (KEYES, 2018, p.20)

7 ROBERTS, D. Post-truth politics. Disponível em: https://grist.org/article/2010-03-30-post-truth-politics/) Cf. também BUCCI, 2018, p.21; SANTAELLA, 2019, p.47.

8 Assim Edward Bernays, sobrinho do psicanalista Sigmund Freud, abre seu livro Propaganda: "A manipulação conscienciosa e inteligente dos hábitos e opiniões organizados das massas é um elemento importante na sociedade democrática. Aqueles que manipulam esse mecanismo oculto da sociedade constitui um governo invisível que é o verdadeiro poder dominante de nosso país" (BERNAYS, 1928, p.9) 
"bombas" de demagogia, propaganda, desinformação, enganação, dissonância cognitiva e instabilidade social Continuamos mentindo e enganando tanto quanto os nossos antepassados; porém, hoje, nos sentimos mais "capazes de enganar os outros impunemente, e mais propensos a sermos dispensados [da responsabilidade, é bom enfatizar] se expostos e, nesse processo, convencemo-nos de que nenhum mal foi feito" (KEYES, 2018, p.18). Portanto, a pós-verdade é, nos termos de Keyes, a circunstância em que "apresentamos razões para manipular a verdade, de modo que possamos dissimular sem culpa" (Ibid., p.20. Grifos nossos), porque a desonestidade é facilitada em uma "sociedade da pós-verdade".

\section{Pós-verdade como mais uma mazela humana}

Alguns autores não veem tanta novidade assim no fenômeno e procuram relativizar o ineditismo de suas características, mas sem desconsiderar os impactos sociais, políticos e psicológicos das práticas relacionadas à pós-verdade, como a massificação das chamadas fake news (notícias falsas, fraudulentas). Por exemplo, para o "verificador de fatos" (fact checker) profissional Tom Phillips, o problema em alegarmos que vivemos numa "Era da Pós-verdade" é a pressuposição de que houve uma "Era da verdade" em algum momento da história humana (PHILLIPS, 2019, p.10) 9 .

Por sua vez, o historiador Yuval Noah Harari pergunta: "quando, exatamente, foi a era de ouro da verdade? [...] E o que desencadeou a transição para a pós-verdade - a internet? A mídia social? A ascensão de Putin e Trump?" (HARARI, 2018, p. 288-9). Segundo Harari, "Os humanos sempre viveram na era da pós-verdade. O Homo Sapiens é uma espécie da pós-verdade, cujo poder depende de criar ficções e acreditar nelas" (HARARI, 2018, p.290). Mais adiante, arremata: “O fato é que a verdade nunca teve papel de destaque na agenda do Homo Sapiens. [...] Na prática, o poder da cooperação humana depende de um delicado equilíbrio entre a verdade e a ficção" (Ibid., p.296). Glenn Kessler (verificador de fatos do Washington Post) segue o mesmo raciocínio de Harari: "Nunca fui fã da palavra 'pós-verdade', pois é um modo simplista de descrever um comportamento humano básico desde que as primeiras palavras foram faladas. [...] As pessoas sempre foram influenciadas pelas emoções e crenças pessoais". Observe que Kessler se contrapõe a definição padrão do Dicionário Oxford. E complementa: "Enquanto verificadores de fatos, entregamos a informação factual e o contexto das alegações feitas pelos políticos. O que as pessoas fazem com esses fatos depende delas".10

Já que, segundo Kessler, os jornalistas deixam nas mãos das pessoas o que devem fazer com os resultados de suas verificações, devemos prestar atenção àquilo que, aqui, chamamos de "responsabilidade epistêmica", cujo espírito é expresso por Harari:

É responsabilidade de todos nós investir tempo e esforço para expor nossos vieses e preconceitos, e para verificar nossas fontes de informação. [...] Não somos capazes de investigar tudo sozinhos. Mas exatamente por causa disso precisamos ao menos investigar com cuidado as nossas fontes de informação preferidas - seja um jornal, um site, uma rede de televisão ou uma pessoa (HARARI, 2018, p.301. Grifos nossos).

O que está em jogo nesse excerto e na última declaração de Kessler são nossas condições e nossos critérios para lidar com fatos e fontes de forma honesta e dispostos a pagar por eventuais ônus gerados pela

9 Vários dos autores aqui mencionados empregam como epígrafe e/ou retomam Hannah Arendt e George Orwell, nas exposições de seus argumentos sobre os precedentes da pós-verdade como insidioso fenômeno político de uso de mentiras, manipulação de fatos, opiniões e narrativas, e propaganda em meados do século XX. Consideramos que o historiador da ciência Alexandre Koyré mereça uma menção por também abordar o assunto em "Reflexões sobre a Mentira", de 1943.

10 https://www.washingtonpost.com/news/the-fix/wp/2016/11/16/post-truth-named-2016-word-of-the-year-by-oxford-dictionaries/ Recuperado em 20 de maio de 2020. Esse tipo de afirmação nos remete, mal comparando, às palavras de Robert Oppenheimer (1904-1967), ao se despedir do projeto Los Alamos, meses após o lançamento da bomba atômica sobre as cidades de Hiroshima e Nagasaki: "É bom entregar à humanidade em geral o maior poder possível de controlar o mundo e lidar com ele de acordo com seus conhecimentos e valores” (BERNSTEIN, J, 2004. Apud. SENNETT, R., 2012, p.14). 
quebra de confiança enquanto agentes epistêmicos e éticos. Mais à frente, retomaremos a posição de um cientista-filósofo do século XIX acerca desse tópico.

Ainda sobre as críticas ao neologismo e seu destaque como uma novidade, em "O guia contra as mentiras: como pensar criticamente na era da pós-verdade" (2019), livro publicado originalmente logo após o coroamento da palavra do ano de 2016, o psicólogo e neurocientista comportamental Daniel Levitin também critica o nosso deslumbramento com fenômenos como a pós-verdade e as fake news. Levitin não parece negligenciar o problema, apenas deflaciona seu apelo. A quase celebração da palavra "pós-verdade" deveria incentivar mais o rápido retorno do uso da "velha e simples" palavra "verdade", acabando com a ideia de que ela não existe (LEVITIN, 2019, p.9). Para ele, "pós-verdade" é apenas mais um eufemismo para mentira, assim como a expressão fake news - outros eufemismos são "contraconhecimento, meias verdades, visões extremas, verdade alternativa, teorias da conspiração" (ibid, p.10) ${ }^{11}$. Nas palavras de Levitin:

A verdade importa. Uma era da pós-verdade é uma era de irracionalidade obstinada, que revoga todos os grandes avanços da humanidade. Talvez os jornalistas não queiram chamar as 'fake news' pelo que são, mentiras, porque não queiram ofender os mentirosos. Mas eu digo a vocês: ofenda-os! Repreenda-os (ibid., p.11).

Para Levitin, a culpa do ensino é a de não ter preparado uma quantidade significativa de pessoas com capacidade para entender estatísticas e números. Ou melhor, o pensamento crítico referido no subtítulo de seu livro se refere a uma competência maior do que essa: a de ser capaz de perguntar de onde os números vieram, como foram coletados, interpretados e apresentados visualmente, entre outras habilidades. O importante é reconhecer argumentos que supostamente trazem fatos cheios de números e estatísticas:

Reconhecer argumentos falsos dentro de histórias ajudará a você avaliar se uma cadeia de raciocínio leva a uma conclusão válida ou não. 'Infoliteracy' significa ser capaz de reconhecer que há hierarquias na qualidade das fontes, que pseudofatos podem facilmente mascarar-se como fatos, e vieses podem distorcer a informação que estão nos pedindo que avaliemos, nos levando a decisões infelizes e a maus resultados (ibid, p.18).

Pensamento crítico, portanto, "significa que devemos tentar distinguir entre afirmações com e sem evidência" (p.17), questionar se a estatística citada em alguma informação é relevante para o ponto em questão. O livro, basicamente, nos auxilia a reconhecer, criticar e evitar falácias lógicas que empregam estatísticas.

O mesmo espírito "ofenda e repreenda os mentirosos com a ciência" se encontra no livro Post-truth (2018), de Lee McIntyre. O filósofo da ciência parte para o ataque à pós-verdade e aos "amigos" dela - aqueles que negam a existência do problema, pois, afinal, (supostamente) ninguém se assume como favorável à pós-verdade e às fake news -, tomando o "negacionismo científico" como um ponto de partida para entendê-la" ${ }^{12}$. Não é exatamente o caso de haver a negação da existência da verdade e dos fatos - vide os exemplos de "teorias marginais" e "fatos alternativos", como o terraplanismo, o criacionismo, o movimento antivacina e a negação das mudanças climáticas provocadas pelo aquecimento global antropogênico. Nega-se a ciência e rejeita-se a autoridade cognitiva dos cientistas porque as teorias consolidadas com base em evidências, experimentos e escrutínio entre os pares especializados e por instituições científicas vão de encontro às perspectivas subjetivas, às preferências pessoais, aos preconceitos e interesses políticos, ideológicos e mercadológicos. Nesse sentido, segundo a definição de McIntyre, a pós-verdade configura o propósito de se subordinar a realidade

11 Para uma lista interessante de eufemismos desse tipo para mentiras e o verbo mentir, ver KEYES, 2018, pp. 22-23: "A desonestidade inspira mais eufemismos do que a copulação ou a defecação. Isso ajuda a nos dessensibilizarmos para as suas implicações. Na era da pós-verdade, não temos apenas verdade e mentira, mas uma terceira categoria de afirmações ambíguas que não são exatamente a verdade, mas tampouco são uma mentira. Pode ser chamada de verdade melhorada. Neoverdade. Verdade suave. Verdade artificial. Verdade light. Através dessa eufemásia, tiramos o ferrão das mentiras." (grifos do autor) 
aos sentimentos e interesses escusos, que são considerados mais precisos do que os fatos - a pessoa "sente" que algo é verdadeiro, logo é verdadeiro; uma teoria positiva impulsiona os lucros da minha empresa, logo é verdadeira. O caráter probabilístico e a avaliação gradual dos motivos, razões ou evidências que dariam suporte ao que afirmo são colocadas em segundo plano. Ou seja, as críticas de McIntyre se enquadram na definição padrão da pós-verdade (aquela do dicionário Oxford), que diz serem colocados de lado os critérios e os valores epistêmicos e metodológicos da comunidade científica.

McIntyre procura explicar essa situação à luz dos vieses cognitivos (psicologia cognitiva) que se apresentam na formação de crenças, na resistência às evidências contrárias e nas tomadas de decisão (dissonância cognitiva, raciocínio motivado, viés da confirmação, efeito Dunning-Kruger, entre outros). De modo geral, o negacionismo científico seria, em boa parte, fruto desses vieses. Trataremos desses assuntos mais abaixo.

Outro caminho aberto para a pós-verdade é o declínio da mídia tradicional, a ascensão das mídias sociais e das fake news (para o autor, isto significa "desinformação deliberadamente criada como se fosse notícia real, de modo a ter efeito político"). McIntyre acusa ambas as mídias de terem apelado para a "falsa equivalência". Isto é, deram cobertura demais às opiniões de leigos e negadores da ciência arrivistas. Estes, geralmente, são políticos e/ou relações públicas e marqueteiros de grandes corporações e grupos ideológicos influentes. Essa acusação nos leva a pensar nos compromissos daquilo que chamamos de responsabilidade epistêmica.

A respeito da "falsa equivalência", dizem o seguinte. Para evitar acusações de parcialidade e partidarismo, a mídia, principalmente a tradicional, abre espaço para posições conflitantes, supondo que dois pontos de vista diferentes possuem o mesmo peso, embora, segundo o autor, seja óbvio que um dos lados apresente condições de demonstrar razões e evidências de estar mais próximo do que seja verdadeiro. Sendo que o outro lado carrega a fama de, não raramente, basear-se em mentiras, equívocos e vieses de toda ordem. Logo, a falsa equivalência se valeria da bem-intencionada e justa promoção do debate, em respeito à igualdade de oportunidades para a livre expressão de opiniões. Contudo, voltando a Levitin, "Não há dois lados de uma história quando um lado é uma mentira” (LEVITIN, 2019, p.10). O problema é que, por apresentarem dados, procedimentos e evidências complexos e contraintuitivos para o repertório do grande público, os métodos e os resultados científicos são "criticados" de forma rasa e inapropriada em rede nacional e internacional, sendo quase imediatamente associados a algum viés político-ideológico. Em suma, o anti-intelectualismo é atitude corriqueira.

\subsection{Ilusões, desconfortos e a demonização do outro}

Chamamos a atenção para os vieses cognitivos e os desafios que impõem ao cumprimento das responsabilidades em relação às avaliações de nossas crenças. Como visto acima, Harari, Phillips, Kessler e McIntyre compartilham, cada um à sua maneira, a tese de que as raízes da pós-verdade fazem parte da história da evolução humana. McIntyre explora essa ideia no terceiro capítulo de Post-truth, intitulado The Roots of Cognitive Bias ("As raízes dos vieses cognitivos"). Para ele, a psicologia social e a psicologia cognitiva vêm, há décadas, investigando o quão racionais nós somos, especialmente diante de constatações que geram tensão ou desconforto psíquico, e os processos psicológicos de ajustar raciocínios e crenças sempre a nosso favor. ${ }^{13}$

O primeiro fenômeno a destacar é a "dissonância cognitiva": a experiência de confusão ao sermos confrontados com informações que sugerem descompassos entre nossos pensamentos, ideias, crenças básicas, fantasias e "o mundo". O fenômeno é muito familiar nas dinâmicas das controvérsias relativas à pós-verdade. Nas palavras da crítica literária Barbara Herrnistein Smith, a dissonância cognitiva se expressa como:

uma impressão de ruído inevitável ou desordem aguda, um aumento de adrenalina, sensações de alarme, uma sensação de desequilíbrio ou caos, sentimentos residuais de náusea e

13 Para uma abordagem didática e bem-humorada desses fenômenos e dos demais a serem apresentados adiante, ver "Você não é tão esperto quanto pensa” (2012) e You are now less dumb (2013), ambos do psicólogo e divulgador científico David McRaney. 
ansiedade. Essas são as formas de aflição corporal que ocorrem quando as arraigadas e pressupostas noções que se tem sobre como as coisas são - e, portanto, presumivelmente serão, $e$ em certo sentido deveriam ser - repentina ou insistentemente confrontadas por alguma coisa muito estranha a elas (SMITH, 2002, p.15).

Somos afetados de tal maneira porque procuramos a harmonia entre nossas crenças, atitudes, comportamentos e aquilo que chamamos de "realidade".

Segundo Smith, comumente, nos colocamos a seguinte pergunta: "Se aquilo em que acredito é verdadeiro ['A' verdade], como o ceticismo ou a crença diferente de uma outra pessoa é possível?" (Ibid.p.17). A tensão está posta, e o "raciocínio" do incauto seria o seguinte: ora, como eu, que sou uma pessoa inteligente e sensata, poderia acreditar em coisas erradas, em falsidades? Afinal, eu acredito em $X$ justamente porque $X$ é "A" verdade ${ }^{14}$. Convenhamos: seria menos doloroso se simplesmente buscássemos investigar e avaliar nossas crenças à luz de análises, razões e evidências (reconhecê-las e avaliá-las já é um grande desafio). Entretanto, para protegermos nossos egos ("os brios"), há a resistência da crença e a busca por ajustes psíquicos nem sempre tão racionais. Geralmente, quase de imediato, afirmamos a "conclusão confortadora" de que o outro está errado, que é um tolo, mal-intencionado, entre outras desqualificações em termos de demonização ou "dementalização" dos opositores, os quais sofrem de "defeitos ou deficiências de caráter e/ou intelecto: ignorância, incapacidade inata, ilusão, treinamento precário, escravização a uma falsa doutrina e assim por diante" (Idem).

Segundo McIntyre, o impacto da dissonância cognitiva é alimentado pelo "raciocínio motivado" e pelo "viés da confirmação". O raciocínio motivado é "a ideia de que aquilo que esperamos que seja verdade possa encobrir nossa percepção daquilo que é verdadeiro". Observa-se a adequação à definição padrão de pós-verdade, pois o raciocínio motivado se realizaria no interior de contextos em que credulidade e elementos emocionais predominariam. Somos motivados a encontrar um modo de racionalização que não ameace nossa autoimagem, reduzindo, assim, o desconforto psíquico diante de circunstâncias adversas às nossas crenças. Esse procedimento "nos leva à tendência irracional para acomodar nossas crenças aos nossos sentimentos, e não o contrário".

Assim, por sua vez, temos a presença do "viés da confirmação": nossa propensão a buscarmos mais confirmações para nossas crenças do que informações, razões e evidências que possam gerar dúvidas ou refutá-las. As bolhas filtradas da internet ajudam a impulsionar esse viés, que é amplificado pela "conformidade social" de um número significativo de pessoas que compartilham das mesmas ideias e/ou dos mesmos preconceitos. As redes sociais da internet proporcionaram em larga escala esse "luxo" de selecionarmos pessoas desconhecidas e variados grupos do mundo inteiro que alimentam nossas crenças e preconcepções sem maiores tensões ou dissonâncias cognitivas.

As resistências às crenças diferentes e ao ceticismo alheio podem chegar ao ponto de questionamentos e evidências contrárias recrudescerem nossas convicções naquilo em que acreditamos ferrenhamente. A esse fenômeno, os psicólogos deram o nome de backfire effect (algo como "efeito do tiro pela culatra"). Determinadas crenças são tão caras a nós que parte de nossa identidade pessoal pode depender delas; logo, qualquer dúvida se apresenta como "gatilho" para tensões emocionais e psicológicas. Outros fatores para uma reação de backfire cognitivo são, por exemplo, os nossos brios e orgulhos, a fidelidade à determinadas visões de mundo e às pessoas que as compartilham. O backfire effect também é alimentado pela desconfiança em relação à autoridade cognitiva de instituições, cientistas e experts em geral. Tendo em vista que qualquer usuário da internet tem acesso a uma quantidade enorme de informações e a um número igualmente exorbitante de assuntos, dados, perspectivas, contrapontos e controvérsias, tendemos a assumir um autoprivilegio epistêmico que ofusca ainda mais a palavra dos especialistas. Afinal, estes também erram (e bastante). A questão é o que fazemos diante dos erros, ou antes, quem somos nós quando estamos com os erros em nossas mãos.

14 Para a Psicanálise, nosso convicto hipotético demonstraria traço paranoico, em vez de sua suposta sensatez. Afinal, neuróticos têm dúvidas; psicóticos têm certezas. 
O incremento para esse viés é o "efeito Dunning-Kruger" (DUNNING; KRUGER, 1999) ou "efeito de superioridade ilusória". Basicamente, esse fenômeno diz respeito à metaignorância (HUANG, 2013, p.415) ignorar que se ignora. E, para alguns de nós, a ignorância pode se parecer muito com a expertise (DUNNING, 2014). Podemos ser tão incompetentes em determinado assunto que não temos capacidade de reconhecer nossa própria inaptidão para tratar dele. Tampouco somos capazes de avaliarmos a complexidade e a dificuldade do assunto ou de uma tarefa, mantendo a ilusão de estarmos acima da média dos demais seres humanos.

Esse viés representa nossa dramática ambivalência em relação às ilusões cognitivas. Por um lado, nos faz levantar da cama todos os dias, mantém nossa autoestima em níveis salutares, protege e consola nossos egos, simplifica e torna aceitável as complexidades do mundo real (MCRANEY, 2012). Por outro lado, nos torna idiotas confiantes, presunçosos, arrogantes, irresponsáveis e patéticos (DUNNING, 2014). Além disso, tem potencial para comprometer carreiras profissionais, organizações, empresas e governos, porque, "a inconsciência da incompetência das 'vítimas' do Efeito Dunning-Kruger provoca um círculo vicioso, pois elas deixam de tomar medidas de autoaperfeiçoamento, continuando incompetentes e incapazes de melhorar" (BRAGA, 2011). Apesar disso, pelo fato de fazer parte de nossos mecanismos de sobrevivência, esse "distúrbio" está tão enraizado em nós quanto a medula óssea (MIGUEL, 2017, p. 279), assim como todo o elenco de vieses cognitivos apresentados acima.

\subsection{Implicações das colocações acima para a divulgação e a educação científica: atenção aos vieses cognitivos}

Há consenso entre os autores de que mentir, manipular, se autoenganar e buscar a autopreservação psíquica (inevitavelmente fantasiar, preferir ficções, confabulações e ilusões) são atividades tão difíceis de eliminar em nós quanto "saltar sobre a própria sombra", como diz um conhecido lugar-comum. Logo, a novidade da pós-verdade não está exatamente nas extrapolações da imaginação, da vontade e da necessidade humana de controle/poder, mas no formato e no alcance de seus resultados, na velocidade como se espalham graças às novas tecnologias de comunicação, e, segundo boa parte dos autores mencionados anteriormente, na dificuldade e/ou desinteresse que temos em relação ao cuidado com nossas crenças pessoais e de outrem. Isto inclui os atos de apontar a mentira, repreender e ofender os mentirosos, repudiar as manifestações designadas pelo neologismo "pós-verdade", mas sempre reconhecendo nosso equívoco, nossa própria falibilidade e nossas limitações para afirmar que "A" verdade em nossas mãos, que dominamos, indubitavelmente, todos os critérios para afirmar o que é o verdadeiro.

Nesse sentido, valorizar a veracidade é um passo comportamental ou uma atitude comprometida com "a verdade" enquanto um princípio regulativo ético-epistêmico, digamos assim. Estar familiarizado com os obstáculos para o cumprimento da veracidade seria um passo importante, e a epistemologia e a lógica se encontraram com os estudos em psicologia cognitiva dos últimos 60 anos para nos ajudar a lidar com isso.

Mesmo que também estejam "enraizadas em nós" e não sejam grandes novidades em termos de manifestação humana, pensamos que divulgadores e educadores científicos (e de quaisquer áreas de conhecimento, incluímos a Filosofia, obviamente) precisam estar atentos aos vieses cognitivos. O elenco de vieses não se restringe aos destacados acima; ademais, é preciso explorar suas interconexões com as heurísticas e as falácias lógicas (KAHNEMAN, 2012; MIGUEL, 2017) para alcançar uma compreensão mais ampla de suas manifestações e consequências, bem como dos modos para lidar com esses fenômenos psicocognitivos e lógicos, especialmente em sala de aula.

Dentre os três, acreditamos que as falácias lógicas sejam tópicos mais comuns nas escolas, em virtude das aulas de Filosofia e ou redação. Da mesma forma, os alunos são introduzidos aos casos de erros de raciocínio (deliberados ou não), deveriam ser confrontados com padrões ou tendências de pensamento baseados em equívocos de memória, ausência de informações ou de acesso direto aos mesmos, equívocos estatísticos, emoções intensas, raciocínio motivado, apatia intelectual entre outros fatores comuns que afetam a nossa cognição. Ao lidar com teorias, conceitos, metodologias e experimentos científicos, acreditamos que a educação 
e a divulgação científica sejam capazes de promover, especialmente em virtude de suas naturezas interdisciplinares, a predisposição do aprendiz a pensar e se comportar à luz da atenção a seus vieses cognitivos e de outras reflexões de ordem epistemológica, metafísica, ética e política. Metacognição, enfim, é o nome do jogo.

Jake Wright (2019) e outros pesquisadores vêm realizando estudos interessantes sobre ceticismo ingênuo e a complacente aceitação da "falação de merda" (bullshiting) ${ }^{15} \mathrm{em}$ forma de (ou baseada em) fake news e teorias da conspiração, principalmente. Um exemplo interessante disso são os alunos do ensino médio desafiando seus professores de física a respeito do formato do planeta Terra ("terraplanismo") ou da teoria da evolução ("criacionismo"/Teoria do Design Inteligente).

Segundo Wright, o ceticismo ingênuo dos estudantes é uma medida defensiva contra informações que confrontam o entendimento que têm sobre o mundo, sobre si mesmos e os valores daqueles que consideram como autoridades intelectuais (mais do que a do próprio professor e/ou cientista). Embora não disponham de suportes teórico e empírico adequadamente considerados, os alunos rejeitam tais informações. O ceticismo é chamado de "ingênuo" porque é adotado acriticamente e sem maiores considerações sobre o que está em questão (WRIGHT, 2019, pp. 119-20). Ou seja, é uma reação semelhante, senão idêntica, à dissonância cognitiva e suas respostas de demonização e dementalização do opositor. Por isso insistimos, enquanto profissionais da educação (incluindo de nível superior), que também realizemos autoavaliações - um trabalho metacognitivo para evitar a metaignorância - de nossas crenças, nossos vieses, dogmatismos, preconceitos, a fim de que possamos ensinar e cobrar de nossos alunos que não caiam tão facilmente em fake news, boatos e bullshit, nem sejam "céticos ingênuos" (WRIGHT, 2019). Outro nome para isso pode ser "negacionismo".

Entre outros problemas, os vieses cognitivos, seus congêneres e desdobramentos, alimentam a "vontade de crer", o "ceticismo ingênuos" e a motivação "emocionada" para confirmar aquilo que já estamos mais do que dispostos a acreditar. Como, afinal, perguntou o matemático vitoriano William K. Clifford (1845-1879), "podemos esperar que outras pessoas nos respeitem pelas verdades [podemos também ler "opiniões"] que trazemos conosco quando cremos em alguma coisa só porque queremos crer, só porque nossas crenças nos confortam e nos são prazerosas?” (CLIFFORD, 1879, p.186). Uma vez que crenças e hábitos de pensamento estão ligados a comportamentos, atitudes e ações que se expressam publicamente, nenhuma crença é, em geral, um assunto privado - de indivíduo ou grupo -, mas concerne à sociedade como um todo. Numa passagem, Clifford nos adverte que "[o] perigo para a sociedade não é tão-somente que possa vir a crer em coisas erradas, embora isto já seja ruim o suficiente, mas que venha a se tornar crédula e perder o hábito de testar as coisas e de investigá-las" diligentemente (Ibid., pp.185-6) (MIGUEL, 2011).

Em sintonia com o pensamento de Clifford, McIntyre alerta para a "credulidade" fomentada pelos vieses, principalmente em se tratando dos "perigos da conformidade ideológica":

Todos temos um viés cognitivo embutido em nós para concordar com o que os outros ao nosso redor acreditam, mesmo se a evidência diante de nossos olhos diz o contrário. Em algum nivel, todos valorizamos a aceitação do grupo, às vezes, mais do que a própria realidade. Mas, se nos importamos com a verdade, devemos lutar contra isso. Por quê? Porque os vieses cognitivos [...] são os precursores perfeitos da pós-verdade (MCINTYRE, 2018).

Fechadas nossas considerações sobre os vieses cognitivos, seguimos com a confusão em relação ao conceito de "verdade" no tempo da pós-verdade.

\section{Sobre uma definição ampliada para a pós-verdade}

Philosphy of Post-truth (2019), de Yael Brahms, procurou ampliar as demais abordagens sobre a pós-verdade por meio de esclarecimentos filosóficos sobre a teoria da verdade pressuposta nas interpretações 
da definição padrão. O principal resultado da empreitada filosófica de Brahms é uma versão ampliada da definição de pós-verdade, a saber:

é um termo que denota circunstâncias em que é enfraquecida a nossa habilidade para clarificar a realidade a fim de entendê-la e agir sobre ela com base nos fatos. Esse enfraquecimento é um resultado da interferência de alta intensidade de quatro [fatores]: a explosão da informação e a tecnologia disruptiva; o enfraquecimento da confiança nas instituições e nos experts; as ideias pós-modernistas; e os aguerridos confrontos políticos.

São abordadas quatro teorias: verdade como correspondência, verdade como coerência, a teoria pragmática (três abordagens neoclássicas) e a abordagem pluralista da verdade (elaborada no final do século XX). O artigo foi publicado na página eletrônica do Instituto de Estudos para a Segurança Nacional, que faz parte da Universidade de Tel Aviv, Israel. Sua abordagem filosófica procura ser um passo preliminar para discutir as implicações da pós-verdade para a segurança nacional e os processos democráticos. Ela procura explicitar o que o fenômeno denota e o que há de novo nele, além de investigar os motivos de sua emergência hoje. Não trataremos de todos esses aspectos. Nosso foco será sobre as teorias da verdade e seu nexo com os fatores mencionados na definição alternativa citada acima.

\subsection{A verdade como correspondência, seus limites e "inimigos tecnológicos"}

Para Brahms, a teoria da verdade como correspondência contempla a definição do Dicionário Oxford e as interpretações sobre a pós-verdade vistas até aqui, já que uma das características mais apontadas do fenômeno é a perda, ou a desvalorização, da verdade baseada em fatos objetivos - supostamente, vermos a mesma coisa, inferirmos e interpretamos o mesmo, aplicando uma mesma linguagem. Segundo essa teoria, a verdade se dá na relação entre linguagem (proposição) e mundo. Isto é, a proposição é verdadeira se, e somente se, corresponder "aos estados de coisa existentes no mundo". A filósofa reconhece que essa é a versão mais intuitiva e popular da verdade. Há uma íntima relação entre aquela teoria da verdade e o realismo metafísico, a concepção de que a realidade e os fatos são independentes daquilo que percebemos, pensamos e sentimos a respeito deles, isto garantiria a objetividade de ambos. Nas palavras de Brahms:

[A] teoria da correspondência ancora a verdade na realidade; essa é a sua força, mas também sua fraqueza. De acordo com a teoria da correspondência, dois critérios devem ser cumpridos para determinar o valor de verdade em uma proposição: em princípio, deve ser possível encontrar o fato relevante no mundo que corrobora com a proposição; e a proposição, ou a pessoa que a enuncia, deve se encontrar em uma relação direta a esse fato no mundo (BRAHMS, 2019. Grifos nossos).

Vamos às fraquezas dessa concepção de verdade. Em primeiro lugar, pode ser difícil ou impossível encontrar um fato que corresponda à proposição enunciada. Isto é muito comum nas ciências naturais e humanas, mas, na ocasião, Brahms emprega exemplos da avaliação dos setores de inteligência da segurança nacional em que informações são recebidas por diferentes pessoas e decisões sérias devem ser tomadas sem os "fatos puros" da comunidade da inteligência de um determinado país (muito em virtude dos limites do segundo critério).

A alegação de um fato dependerá também de sua coerência em relação ao conhecimento prévio que a organização de inteligência possui sobre determinado assunto sensível. Além disso, diz Brahms, o valor de verdade da alegação pode se basear nos "objetivos que os tomadores de decisão querem alcançar; nas opiniões e crenças pessoais daqueles que se sentam à mesa em que as decisões são tomadas; e também das considerações políticas e agendas pessoais". Ou seja, outras teorias da verdade - no caso, a coerentista e a pragmática - são acionadas. Contudo, como é bem sabido, a situação descrita não é exclusiva do âmbito dos órgãos de inteligência, nem uma novidade trazida pelo fenômeno da pós-verdade. 
O mesmo acontece com o segundo critério: a relação direta entre o enunciador da proposição e o fato no mundo. Isto é, a oportunidade de encontrarmos testemunhas confiáveis para verificar diretamente se a proposição é o caso. Segundo Brahms: "Mesmo que o primeiro critério seja cumprido, e o valor da verdade de uma proposição possa, a princípio, estar ancorado na realidade, essa possibilidade nem sempre está disponível a todos, e, na corrente era, isto é quase inacessível para nós". A referida "corrente era" é a da informação, com suas tecnologias de criação, propagação e consumo alucinantes de informação provenientes de diferentes fontes.

Segundo a autora, a teoria da verdade como correspondência não é, portanto, muito útil na era da explosão informacional: "os consumidores de informação não têm um modo de clarificar o valor de verdade da maioria da informação disseminada [...] via mídia, internet e redes sociais - porque, em muitos casos, [eles] não estão em relação direta com os fatos relevantes". Um cenário que ilustra essa situação é a "diminuição do tamanho" do mundo em termos de comunicação, o nível de massificação e a velocidade com que as "narrativas alternativas" e suas congêneres dão a volta na Terra. Isto compete com as iniciativas dos mais escrupulosos com o dever da investigação, da veracidade e da apuração conscienciosa das alegações sobre fatos. Os epistemicamente responsáveis sofrem dissonância cognitiva, se indignam e se revoltam, inicializam seus computadores, ou avaliam fontes em seus smartphones e/ou partem para uma biblioteca. Nesse ínterim, as afirmações deliberadamente ambíguas, as totalmente falsas, as parcialmente verdadeiras e suas várias versões já "correram o mundo", ganharam adeptos, formaram legiões, acabaram com reputações e levaram ditadores ao poder de forma suspeita e/ou violenta.

Ademais, há a desconfiança em relação ao testemunho alheio. Em quem se deve confiar, especialmente diante da explosão das "deliberadas investidas de informação falsa" (fake news), das bolhas filtradas e das "câmaras de eco"? O declínio da confiança do público a respeito da mídia tradicional e, principalmente, das instituições científicas, das universidades, dos cientistas, e dos reconhecidos especialistas, ou experts, em várias áreas do conhecimento é um outro obstáculo para a possibilidade do cumprimento do segundo critério da teoria da correspondência. ${ }^{16}$ Assim como os demais autores referidos anteriormente, Brahms destaca os riscos de todas essas características para um país democrático. Como decidir em quem confiar e eleger como representante? Para isso, os eleitores precisam saber "diferenciar entre verdade e opinião, entre uma mentira deliberada e um erro inadvertido" (mesmo que quem errou pouco se importe com a informação correta). Dadas todas essas circunstâncias, os eleitores

não são capazes de basear seus votos somente em fatos objetivos, e são requisitados a preencher as lacunas em seus conhecimentos usando um conjunto de crenças e opiniões pessoais, [baseando-se em] seus sentimentos para este ou aquele político, [em] sua confiança, ou falta dela, em várias fontes de informação, e na interpretação pessoal da informação corrente (BRAHMS, 2019).

Em suma, essas características da era da pós-verdade complicaram ainda mais a já problemática "conexão intuitiva" que a teoria da correspondência, a princípio, estabeleceria entre observação, pensamento, linguagem, fatos, verdade e mundo/realidade. Contudo, as dificuldades dessa teoria da verdade não são novidades, dadas a presença e as elaborações de suas concorrentes ao longo da história da filosofia.

\subsection{A "concorrência"}

Diferente da concepção anterior, a teoria coerentista da verdade não "ancora a verdade na realidade". Em especial, isto quer dizer que uma proposição pode ser considerada verdadeira mesmo que seja difícil encontrar um fato no mundo que corresponda diretamente a ela, ou que o enunciador da proposição tenha contato direto com o fato. Para a teoria coerentista, a chave para a verdade está na relação entre proposições: o

16 Para aprofundamentos sobre o declínio da confiança nos especialistas e no conhecimento estabelecido ("a morte da expertise"), ver MANJOO, 2008, capítulo 4; e NICHOLS, 2017. 
valor de verdade de uma proposição está em sua coerência com um conjunto ou rede de crenças. Observa-se que, enquanto a teoria da correspondência pressupõe o realismo metafísico - a independência da realidade em relação à consciência humana -, o coerentismo se aproxima do idealismo metafísico. A realidade não é negada, mas considera-se que não seja independente da percepção e da cognição humana. Logo, há a determinação de que a verdade tenha uma fundamentação (e justificação) epistemológica em algum sistema de conhecimento, prescindindo de uma fundamentação ("ancoragem") ontológica na realidade. Seria o caso de trocar o critério da verdade pela plausibilidade.

Para Brahms, um problema exemplar, focado em sua audiência, é o do oficial de inteligência cheio de convicções (ou paranoias) sobre um suposto inimigo do estado. Se a verificação das suspeitas por meio de fatos objetivos for difícil (dadas as mencionadas fraquezas da teoria da correspondência), sendo, por esse motivo, deixada de lado, o que impediria o oficial de continuar firme em sua convicção se esta for coerente com o que sabe acerca (ou espera) do suposto inimigo? E se for plausível para o seu estado cognitivo?

Algumas respostas possíveis: as objeções e as críticas dos pares, e/ou cautela, suspensão de juízo e busca por acesso a mais informações, e/ou autoavaliação da capacidade de julgar o caso. Contudo, restariam dúvidas de que tais sugestões sejam suficientes, em virtude da urgência da decisão, dos protocolos profissionais, dos objetivos e interesses em jogo, dos vieses cognitivos das pessoas envolvidas na decisão, dentre outros fatores e circunstâncias.

Já que a verdade não está ancorada na realidade (não é exatamente um suposto acesso pessoal, individual, direto, claro e distinto ao mundo que determina a verdade ou a falsidade das proposições), mas em um sistema de crenças, conhecimentos ou teorias, a atenção deve incidir sobre a plausibilidade e o poder de persuasão das proposições (e da argumentação) empregadas para justificar as objeções às convicções do oficial hipotético. Nesse sentido, o que deve ser atingido é o "estado cognitivo do agente". Definimos estado cognitivo como

o conjunto de crenças ou conviçcóes que o agente tem, aquilo que o agente julga saber, o que ele pensa ser falso, o que ele aceita apenas parcialmente, o que ele duvida etc. O estado cognitivo do agente é a base a partir da qual avalia não só os argumentos que lhe são apresentados, mas toda e qualquer nova informação (MURCHO, 2015, p.100).

Podemos pensar que, se assim for, seríamos facilmente levados por vieses cognitivos e pessoas manipuladoras; entretanto, Desidério Murcho se antecipa:

Ora, a única maneira racional de reagir quando alguém procura influenciar o nosso estado cognitivo é avaliar cuidadosamente essa proposta; e não há outra maneira de o fazer exceto usando os elementos relevantes do nosso estado cognitivo. Não se trata de dizer que avaliamos tudo segundo o nosso próprio ponto de vista, fazendo de cada agente cognitivo uma espécie de ilha cognitiva isolada e incomensurável. Se alguém se recusa aceitar novas informações empíricas claras, por exemplo, porque colidem com as suas crenças prévias, essa pessoa é dogmática e irracional. A racionalidade é algo que se situa entre o dogmatismo e leviandade (Ibid, p.102).

Vamos aproveitar essa argumentação para fazer algumas reflexões.

Para o epistemólogo social Steve Fuller, a teoria da correspondência indaga se uma proposição corresponde à realidade ("ou está fora de questão?"); a coerentista, por sua vez, indaga se "a realidade é tudo o que se afirmou (ou algo importante foi descartado?)". Fuller segue com o exemplo dos tribunais: 
Os tribunais se propõem a alcançar "toda a verdade e nada além da verdade". Infelizmente, como os intelectuais bem sabem, as duas tendências se combatem. O foco em "nada além da verdade" é, de certa forma, conservador: erra-se ao excluir incertezas por medo de que escondam falsidades. Em contraste, o foco em "toda a verdade" é mais liberal [progressista]: erra-se ao incluir incertezas na esperança de que possam revelar verdades. Até mesmo a lei reconhece implicitamente o dilema em suas infindáveis disputas entre "letra" e "espirito" (FULLER, 2006, p.53).

A partir do que vimos nas seções anteriores, Fuller parece inverter os posicionamentos axiológicos dos lados em disputa. Os "promotores" da pós-verdade seriam mais liberais (antidogmáticos?), enquanto os anti-pós-verdade seriam conservadores (dogmáticos?). Os críticos diriam que esse tipo de inversão de valores é bem próprio dos intelectuais pós-modernos.

Determinadas características atribuídas por Fuller à visão coerentista podem ser encontradas na teoria pragmática da verdade. Nas palavras de Brahms, para essa concepção, a "chave para a verdade está na utilidade". Nós diríamos que está na ação. Ela segue: "o valor de verdade de uma proposição é determinado de acordo com seus resultados práticos e a utilidade que proporciona”. A concepção pragmática seria mais uma interpretação da teoria da correspondência do que propriamente uma definição alternativa para a verdade. Segundo a filósofa, a interpretação pragmatista aceita o realismo metafísico e não nega a existência da verdade factual; entretanto, está mais próxima do coerentismo porque, diríamos com Fuller, seus defensores não teriam medo de errar ao "incluir incertezas na esperança de que possam revelar verdades". Mesmo que incertezas e erros sejam incluídos, o quanto de plausibilidade as virtudes intelectuais e os juízos epistêmicos são capazes de e estão legitimados a incorporar a fim de não censurar "a abundância da realidade" (seguindo o espírito de Feyerabend)?

O contato cognitivo com a realidade é difícil, e somos seres falíveis, de modo que processos de tentativa-e-erro e improvisos se fazem presentes. Ao que se refere à atividade científica, nos diz Brahms, os pragmatistas afirmam que nunca sabemos ao certo se as teorias são verdadeiras ou não, de modo que a certeza possível em relação a elas se encontra nos padrões aceitos por uma determinada comunidade científica sobre sua adequação empírica, seu poder de previsão e de explicação. Há graus de aproximação da realidade.

Por outro lado, critica-se a teoria pragmática da verdade porque promove uma abordagem relativista - se a utilidade é o critério, coloca-se o problema de que algo pode ser útil para uns, mas não para outros (casos ou agentes beneficiados). Como decidir? Que ações serão mobilizadas no mundo cujas consequências julgarão e darão razão à determinada crença com pretensões de conhecimento?

Nesse sentido, a teoria pragmatista, talvez, possa ser a preferida de "ícones da pós-verdade", como o ex-presidente do EUA Donald Trump, os relações públicas das grandes indústrias, os gurus do mercado da autoajuda e pessoas afeitas ao pensamento mágico: alguma coisa é considerada verdadeira para alguém ou a um grupo porque é/foi útil para os fins almejados - "verdades materializadas". Se, a partir da minha opinião/ crença, mobilizo, em mim e em outras pessoas, vontades, comportamentos, atitudes e ações que beneficiam a minha causa e/ou a de meu grupo, então ela é verdadeira, não obstante a ausência de evidências públicas e notórias no mundo para sustentá-la. O importante é que ela tem efeitos na realidade. Em algum momento, a realidade pode dizer "não", mas efeitos foram atingidos, para o bem ou para o mal, bastando uma mudança de contexto e de perspectiva para ocorrer uma "flexibilidade" dos fatos ("fatos alternativos" em estilo trumpista).

Decerto, podemos estar exagerando em nossa associação da teoria pragmática (e não é incorreto incluir a coerentista) com o modus operandi de figuras moral e politicamente suspeitas. No entanto, esta parece ser a desconfiança de Brahms em relação às concorrentes da teoria da verdade como correspondência. No final das contas, a pergunta de fundo é Cui bono? - quem se beneficia e como com a diversidade de teorias e interpretações sobre a verdade?

Por sua vez, para a abordagem pluralista do conceito de verdade, como se pode inferir, há vários conceitos de "verdade" aceitáveis de acordo com esfera de ação. Afirma-se o caráter ambíguo desse conceito, que 
pode se manifestar de diferentes maneiras. Para cada manifestação da verdade, há diferentes definições de critérios que podem ser adotados em tópicos diferentes. Nas palavras de Brahms,

A diversidade conceitual da "verdade" pode ser dividida de acordo com a diversidade dos tópicos de discurso, tais como verdade científica, verdade da segurança nacional, verdade moral, verdade judicial, verdade artística e verdade política, ou de acordo com a variedade de modos empregados para determinar o valor de verdade, tais como a verdade factual, a verdade por coerência e a verdade pragmática.

À luz da abordagem pluralista, esses três modos de determinar o valor de verdade não excluem uns aos outros, mas se justapõem e se complementam em variados tópicos. Por exemplo, aparentemente a verdade científica e a verdade da segurança nacional se baseiam na verdade factual (segundo Brahms, "é assim que deveria ser"), mas não de forma absoluta, de modo que podemos encontrar as concepções coerentistas e pragmatistas da verdade somadas à verdade factual objetiva. Isto é possível porque a ciência e a segurança nacional não dependem apenas dos fatos "puros" (afinal, o que seria isso?). A abordagem pluralista leva em conta que ambos os campos também dependem do "acúmulo de conhecimento organizacional, de experiência profissional, de agendas e políticas, de opiniões e crenças pessoais”. Assim sendo, no caso da segurança nacional, Brahms diz que, pela perspectiva da versão pluralista, as verdades coerentista e pragmática "preenchem as lacunas deixadas pela verdade factual, servem aos objetivos que os tomadores de decisão querem alcançar, e influenciam o modo pelo qual transmitem verdade factuais".

A despeito de parecer uma abordagem promissora, a autora não a explora tanto, tampouco o faremos aqui. Não obstante, cabe uma menção aos fatores que tornam a teoria pluralista interessante, a saber: considerações às contingências, limitações, temporalidade, historicidade e competências individuais e coletivas para lidar com as complexidades e os ruídos entre julgamentos que, supostamente, deveriam ser idênticos.

\subsection{0 caso da pós-modernidade}

A maioria dos autores examinados por nós e por Yael Brahms apontam as ideias dos intelectuais pós-modernos a respeito da verdade, do conhecimento, da ciência e da objetividade, entre outros conceitos, como corresponsáveis pelo surgimento da pós-verdade ${ }^{17}$. Colocado de forma bastante resumida, o pós-modernismo surge, nos anos 1960 e 1970, no meio das Artes, especialmente na crítica literária, ganhando terreno em outras áreas da Filosofia e das Ciências Humanas.

Uma característica central do pensamento pós-moderno é a crítica aos valores do Iluminismo europeu, como a razão, a verdade, a objetividade dos fatos, a neutralidade, a imparcialidade e "o" método da "Ciência". Como esses valores iluministas redundaram em guerras, opressões e massacres sociais, políticos e culturais severos no século XX, a "pureza" e o autoprivilegio epistêmico e moral pressupostos no discurso oficial da "Razão", expresso mediante as Ciências, passaram a ser questionados com maior profundidade. O fenômeno do multiculturalismo também ajudou nesse processo ao relativizar a visão absolutista da superioridade da "razão ocidental, europeia, branca, masculina, heteronormativa e cristã".

Investigações mais aprofundadas mediante mudanças metodológicas na filosofia, na história e na sociologia da ciência complexificaram as discussões sobre a natureza da atividade das ciências, a racionalidade e o modo como decisões teóricas e conceituais são tomadas dentro das comunidades científicas e alhures. Revelaram-se ao longo do processo os mitos e os interesses políticos por trás das supostas certezas que ofereciam parte considerável da sustentação da autoridade das ciências. As filosofias, histórias e sociologias das ciências de cunho pós-moderno procuraram inserir a sociedade na ciência. O objetivo não era eliminar a

17 Como exemplos, Cf. D’ANCONA, 2018, pp.83-98. Para D’Ancona, na filosofia pós-moderna encontram-se as raízes da pós-verdade. Ver também https://www.theguardian.com/science/2017/feb/12/daniel-dennett-politics-bacteria-bach-back-dawkins-trump-interview Recuperado em 18 de maio de 2020 
existência da realidade, da verdade e das ciências e suas instituições da face da Terra, mas, sim, tentar mostrar o quanto são reducionistas, totalitárias e enviesadas as concepções iluministas, ou ortodoxas, daqueles conceitos.

Os pós-modernos rejeitam a existência de uma meta-narrativa única e objetiva capaz de explicar todo e qualquer fato; no entanto, não afirmam a inexistência de fatos e de verdades factuais em si (BRAHMS, 2019). O que está em jogo é o entendimento de que estes nem sempre são suficientes para a tomada de decisões entre várias teorias e narrativas. Portanto, conforme Brahms mostra em sua caracterização dos limites da teoria da verdade como correspondência, outras teorias da verdade entraram em cena na ciência.

Em termos de posicionamento político, o pós-modernismo se localizaria à esquerda no espectro político. As intenções intelectuais e sociais eram, supunha-se, as melhores, mais humanistas e pluralistas. Criticar a assimetria cognitiva e moral das ciências e dos cientistas (bem como dos "donos do poder") era, entre outras coisas, uma medida social e política em defesa e pela preservação de outros modos de vida (de ser, de existir, estar no mundo, florescer e atualizar potencialidades) e de racionalidade diante do absolutismo epistêmico de determinados grupos hegemônicos, e de suas narrativas e meta-narrativas. Ou seja, recordando o físico e filósofo da ciência Paul Feyerabend (1924-1994), era uma medida de adequação do empreendimento científico dentro de regimes democráticos dignos desse nome, a fim evitar outras versões de totalitarismo "esclarecido" (FEYERABEND, 2011; MENDONÇA, A; ARAUJO, P.; VIDEIRA, A., 2010).

Os pensadores pós-modernos de esquerda também vêm sendo atacados, especialmente nos últimos cinquenta anos, porque, embora seja um movimento intelectual politicamente identificado com ideais progressistas, deram condições teóricas e metodológicas para a direita conservadora elaborar seus discursos de negação da ciência e de manipulação das narrativas mediante a deliberada confusão entre teorias da verdade e teses pós-modernas referentes aos estudos filosóficos, históricos e sociológicos sobre as ciências. De modo geral, a direita dita "conservadora" - políticos, relações públicas e cientistas ligados a vários setores industriais - lança mão oportunamente de "espantalhos" (caricaturas grotescas e distorcidas) da abordagem do construtivismo social sobre a relação entre ciência, verdade e fatos (DENNETT, 2017; D’ANCONA, 2018; MCINTYRE, 2018).

O problema é a confusão deliberada que determinados setores ideológicos e político-industriais fazem nos discursos em defesa de suas agendas. Grosso modo, por exemplo, qualquer objeção baseada em experimentos, dados e evidências a favor da teoria do aquecimento global antropogênico será rebatida em virtude da desconfiança em relação à objetividade dos pesquisadores do clima - os dados nunca serão suficientes, as evidências não serão as adequadas, interesses político-ideológicos (muitas vezes, conspiracionistas) serão alegados no processo. Essas estratégias dos "mercadores da dúvida" são criticadas, aproximadamente, desde os anos 1980; contudo, ainda há muitas dificuldades para eliminá-las, por mais que sejam denunciadas e expostas publicamente. $^{18}$

Tomemos o mui recorrente exemplo da abordagem do construtivismo social do sociólogo francês Bruno Latour, que ainda está na ativa e lamenta o que foi feito de seu trabalho e de muitos de seus colegas (LATOUR, 2004). Resumidamente, para Latour, o caráter não objetivo dos fatos não implica na inexistência deste nem da realidade, mas apenas que, contrariando concepções "objetivistas" ou "fundacionalistas" (SMITH, 2002), os fatos são contingentes, dependem da consciência e das atividades humanas, "são criados ou 'construídos' durante o processo humano de pesquisa científica" (BRAHMS, 2019). Ainda citando Brahms:

Portanto, de acordo com Latour, o fenômeno da pós-verdade não é um produto de suas ideais e das de seus associados; mais do que isso, o fenômeno valida essas ideias: quando pessoas se colocam em relação a um fato como se este fosse um produto da estrutura da pesquisa científica, que é sustentada por uma 'rede' de instituições e metodologias de pes-

18 Filmes e documentários retratam bem essa situação, tais como "Obrigado por fumar" (2005), baseado no livro homônimo de Christopher Buckley (1994); "Mercadores da Dúvida" (2014), dirigido por Robert Kenner, baseado no livro Merchants of Doubt: How a Handful of Scientists Obscured the Truth on Issues from Tobacco Smoke to Global Warming, dos historiadores da ciência Naomi Oreskes e Erik Conway (2010). 
quisa, torna-se mais fácil entender que, quando a sustentação da rede enfraquece, os fatos que "construiu" e apoiou são enfraquecidos também.

Tudo isso pode soar (ou já soou) muito anti-intuitivo para cientistas e defensores da ciência mais ortodoxos (dogmáticos?). Todavia, não é a própria ciência uma geradora de ideias (hipóteses, conceitos, teorias, experimentos) que são, de início e na maioria das vezes, anti-intuitivas, porque, entre outros efeitos, torna a realidade mais complexa, interligada e abundante do que podemos perceber de imediato, a olho nu e/ou através de inspeção rápida e não acurada? Nos termos que empregamos aqui, não seria da natureza da ciência provocar, num primeiro momento, incômodos ou, no limite, dissonâncias cognitivas? Nesse sentido, malgrado o dogmatismo epistêmico-metodológicos de cientistas mais ortodoxos, a filosofia, a história, a sociologia e a psicologia das ciências estão aí para provocar as mesmas reações.

Não obstante Latour tenha ido a público reafirmar sua defesa da ciência e das instituições contra o que foi feito do pensamento pós-moderno, tanto nas mãos de seus simpatizantes, quanto nas estratégias escusas dos oportunistas (LATOUR, 2004), o estigma se mantém: as ideias do pós-modernismo são as precursoras (ou fundadoras) da nossa condição de pós-verdade, pelo menos no que diz respeito ao "discurso populista pseudo-pós-modernista" da direita conservadora (BRAHMS, 2019). Esse discurso deriva de uma redução ou distorção das ideias pós-modernas.

Mesmo o efusivo crítico Lee McIntyre concorda com isso, e acredita que os pós-modernos, especialmente aqueles ligados aos chamados Science Studies ${ }^{19}$, possam esclarecer e corrigir os usos equivocados e mal-intencionados de suas teses e posições. Tais esclarecimentos, espera-se, seriam capazes de contra-atacar os abusos da versão da pós-verdade impulsionada pelo ceticismo desonesto (o negacionismo) e pela manipulação da realidade proporcionada pela direita dita "conservadora" (McIntyre tem em mente, em especial, o ex-presidente Donald Trump e alguns de seus correligionários do Partido Republicano). Apesar disso, o filósofo da ciência não deixa de ser severo:

Que fracasso [foi] a política original que motivou o pós-moderno, que era proteger os pobres e os vulneráveis da exploração das autoridades. Agora, são os pobres e os vulneráveis que sofrerão mais com as mudanças climáticas. [...] Como a esquerda lutará contra a ideologia da direita sem usar fatos? Esse é o preço de se brincar com ideias como se não tivessem consequências. É muito divertido e bacana atacar a verdade na academia, mas o que acontece quando essa tática cai nas mãos daqueles que negam a ciência, dos teóricos da conspiração, ou nas mãos de políticos sensíveis, que insistem que seus instintos são melhores [parâmetros] do que qualquer evidência? (MCINTYRE, 2018, cap. 6).

\section{Disputas pelo monopólio da realidade}

Na definição de Brahms para a pós-verdade, o último fator para o enfraquecimento da nossa "habilidade para clarificar a realidade a fim de entendê-la e agir sobre ela com base nos fatos" é a disputa política para definir os critérios da verdade. Ou melhor, "batalhas políticas", nos termos da autora. As características dessas batalhas, atualmente, são consequências das interferências dos demais fatores expostos anteriormente. Um outro diferencial da definição de Brahms é a falta de ênfase nas emoções na explicação sobre a pós-verdade.

Vimos que os aspectos emocionais e políticos do fenômeno recebem destaque inicial em quase todas as abordagens anteriores, pois seguem a definição padrão. Os juízos de valor a respeito do posicionamento do "lado inimigo" - direita conservadora "pseudo-pós-modernista", esquerda pós-moderna, negacionistas da ciência, mídias sociais ideologicamente engajas, criadores e disparadores de fake news, entre outros - chamam

19 Denominação genérica para o campo transdisciplinar de estudos de filosofia, história e das ciências sociais sobre as ciências, identificados no Brasil como "Estudos de Ciência, Tecnologia e Sociedade" (CTS). Cf. VIDEIRA, 2005; MENDONÇA, 2012). 
a atenção para as "falhas" emocionais, cognitivas, psicológicas, morais e epistêmicas dos "promotores" da pós-verdade. Tal reação, pode-se afirmar, faz parte da desconfortável experiência com a dissonância cognitiva, que se expressa, frequentemente, em forma de indignação e revolta, diante de ações afrontosas, como a proliferação de falsidades e bravatas.

Contudo, Brahms evita tomar esses elementos como ponto de partida, preferindo ir da identificação do conceito de verdade pressuposto nas interpretações sobre a pós-verdade, mostrando seus limites, bem como as disputas com suas concorrentes na era da explosão informacional e suas tecnologias, as quais amplificam a confusão a respeito dos critérios para avaliar o que é verdadeiro e o que é falso no tsunami de discursos e narrativas. O "consumidor de informação" está distante dos fatos relevantes e o acesso a tantos "fatos alternativos" em questão de segundos, sem maiores critérios de avaliação da veracidade das mesmas, parece fazer de cada pessoa um expert para si mesmo em todo e qualquer assunto, sendo isto um dos motivos para a perda de credibilidade das instituições, dos acadêmicos, cientistas e especialistas em geral.

Contudo, parte da responsabilidade pelo "declínio da fé" nas instituições e em seus especialistas recai sobre as ideias relativistas, construtivistas, "anti-iluministas" dos intelectuais pós-modernos. Apesar das intenções progressistas destes, os inimigos da pós-verdade os acusam de terem oferecido condições intelectuais e metodológicas para os oportunistas negarem a ciência, fazerem malabarismos com os critérios e valores de verdade, manipularem fatos e promoverem o caos informacional para fins políticos. Aqueles que se identificam como intelectuais pós-modernos afirmam que suas ideias e as de seus antecessores foram distorcidas. Segundo Brahms,

Conservadores de direita usam essas ideias distorcidas como ferramentas para atacar a esquerda liberal e proporcionar maior peso à interpretação subjetiva e a diferentes tipos de verdade, tais como a coerentista e a pragmática, em campos como a ciência e a segurança nacional, nos quais o peso primordial deveria ser dado à verdade factual (BRAHMS, 2019).

Esse excerto é bastante revelador sobre as posições de Brahms: uma adepta da atitude realista, defensora da teoria da verdade como correspondência, desconfiada das demais concepções e, a princípio, contrária à direita conservadora. Brahms valorizaria mais a atenção à verdade factual, aos fatos objetivos, à realidade. Embora tenha suas fraquezas, a concepção da verdade como correspondência seria menos propensa ao relativismo cognitivo, seria menos "frouxa" e aberta ao "peso da interpretação subjetiva" dos oportunistas, bem como aos fatores e circunstâncias mencionados acima. Ou seja, o perfil de Brahms é semelhante ao da maioria dos inimigos da pós-verdade que apresentamos.

Para explanar as dificuldades envolvidas nas disputas políticas - entre esquerda e direita, progressistas contra conservadores, ciência contra a religião, por exemplo -sobre as narrativas, Brahms aborda a tese da "subdeterminação" das teorias pela evidência empírica. A "tese Duhem-Quine"20 é muito familiar aos filósofos da ciência. Basicamente, a tese afirma que uma evidência empírica pode ser explicada por teorias diferentes, até mesmo por teorias contraditórias, tais teorias também seriam capazes de prever com precisão os mesmos fatos empíricos. ${ }^{21}$ Logo, não é a evidência que determinaria a aceitação de uma teoria como sendo a verdadeira. Segundo a leitura de Brahms, "a verdade factual não seria suficiente para a tomada de decisão entre duas narrativas e para a decisão de qual delas é verdadeira”. Não é novidade dizer que a filosofia, a história e a sociologia da ciência vêm discutindo isso há anos, especialmente após a repercussão do trabalho seminal de Thomas Kuhn (1922-1996), a "Estrutura das Revoluções Científicas” (1962).

O temor de Brahms está no uso distorcido da tese Duhem-Quine pelos promotores da pós-verdade, pois, para qualquer narrativa $N$ que descreva e explique determinados estados de coisas no mundo com base em evidências empíricas, é possível que exista uma narrativa $N^{\star}$ que exiba as mesmas qualidades, mas apresentando

21 O exemplo clássico é o das teorias sobre a extinção dos dinossauros: há evidências que sustentam tanto a versão do choque de um meteoro contra a Terra, quanto a versão do bloqueio do Sol por nuvens de poeira geradas por intensa atividade vulcânica. 
o mundo como sendo de outro modo. Se só forem levados em conta as versões coerentistas e pragmatistas da verdade, já que as condições da verdade como correspondência aos fatos são mais difíceis de serem atendidas, toda e qualquer versão do mundo poderia ser aceita com base em crenças, opiniões e preferências pessoais. Os debates sobre aquecimento global, antivacinação e terraplanismo, a polarização político-ideológica no Brasil, a proliferação e aceitação de fake news e de teorias da conspiração são bons exemplos disso.

As questões seguem sendo: quais serão os critérios comuns para decidirmos qual narrativa será aceita? Qual abordagem sobre a verdade prevalecerá? Talvez, a pergunta central seja a respeito de quem estabelecerá os critérios: cientistas, acadêmicos, juízes, jornalistas profissionais? Segundo a autora,

Na era da pós-verdade, o poder de decidir entre narrativas não é mais mantido pelas fontes costumeiras de autoridade, antes, é mantido por qualquer um que se oponha a tais fontes de autoridade (os apoiadores de Trump ou governantes que agem como ele, e os Brexiteers) $e$ afirma narrativas alternativas, que foram, outrora, consideradas falsas ou impossiveis, mas, hoje, são aceitas pelo menos como alguma coisa que parece verídico, ou como algo que pode ser considerado uma verdade plausível.

Em que momento da história humana não foi assim (só que com papéis sociais um pouco diferentes)?

\section{Considerações finais}

O diagnóstico de Brahms reafirma que não são triviais os desafios impostos pelas características da pós-verdade e pelos fatores que lhe sustentam e propulsionam. Ancorando-nos nas evidências que a realidade ("atual conjuntura") arremessa em direção aos nossos olhos, sendo coerentes com os esclarecimentos conceituais, obstáculos à verdade e fatores para a pós-verdade, e levando em consideração a utilidade prática das proposições de Brahms para nossas reflexões, é inevitável concluir que, como sói acontecer, decisões e atitudes, ainda que provisórias, devem ser tomadas em relação aos nossos posicionamentos enquanto agentes cognitivos, epistêmicos, éticos e políticos envolvidos, direta ou indiretamente, com divulgação, educação e valorização das ciências.

Nada disso é novo, repetimos. Basta estudar as histórias da filosofia e da ciência de diferentes perspectivas historiográficas. Continuamos os mesmos, confusos e dissimulados, só que mais sofisticados tecnologicamente, sobrecarregados de informações falsificadas nas redes sociais para fins políticos (GENESINI, 2018), supostamente sem tempo, apressados demais para ponderar, superestimulados pelas (e, ao mesmo tempo, entediados com as) várias opções de ideias, narrativas e modos de viver que circulam em frenesi ao nosso redor. Entretanto, esse tipo de constatação não será útil, caso se torne uma justificativa para sermos complacentes, dogmáticos ou levianos com o processo de formação da concepção de ciência e de responsabilidade epistêmica das próximas gerações. Ao afirmar isso, reforçamos a convicção de que a educação científica articulada à filosófica e demais ciências humanas é uma medida de enfrentamento às "desonestas disputas pela realidade".

Decerto, se estamos falando tanto da verdade, tratar das questões acerca das teorias da verdade é uma tarefa primordial diante da exposição constante dos estudantes ao fenômeno da pós-verdade. A exposição é constante e confusa, porque "a partir das fragmentações de espaço e tempo, a sala de aula transcende para redes sociais e torna-se um espaço de aprendizagem. E como 'acreditar' no que é vinculado e manipulado já que ninguém detém o monopólio da verdade?” (SANTANA; MARQUES; PINHO; 2017, p.99). Mesmo correndo o risco relativista de supor que todos "estaríamos com a verdade", concordamos que ninguém tenha o monopólio do que seja verdadeiro, já que "a verdade é o ponto final da conversa [ou] pelo menos quando alguém reivindica acesso à verdade, os limites da continuidade da conversa são levantados" (FULLER, 2006, p. 52). Todavia, à luz do artigo de Brahms, não detemos o monopólio de qual verdade? Qual verdade seria o "ponto final da conversa"? 
Mais uma vez, nos parece que apenas a verdade factual, identificada com teoria da verdade como correspondência importaria, com todo o apelo intuitivo do realismo metafísico. Porém, como vimos acima, as fraquezas dessa teoria e a existência das concorrentes demonstram o quão árduo é cumprir seus requisitos, abrindo margem para o "preenchimento das lacunas" a partir da admissão de outras chaves para a verdade - a coerência de proposições com um sistema/bloco de crenças, narrativas ou teorias; ou a utilidade e os resultados práticos alcançados com as proposições; ou, por sua vez, a justaposição e a complementariedade desses diferentes valores de verdade em âmbitos intelectuais diversos. Antes de uma determinação dogmática ou leviana, ou simplesmente apressada, precisamos ajudar os estudantes (e o público interessado) a compreenderem as complexidades das teorias da verdade. Qual(is) "verdade(s)" seria(m) propícia(s) para o início de uma conversa sobre parâmetros/critérios/valores a respeito do que seja verdadeiro? Particularmente, pensamos que o "ponto final da conversa" não seja exatamente a verdade, mas o medo patológico de errar, o dogmatismo, a conviç̧ão cega, a vontade de acreditar, a paranoia de se estar com a certeza.

Compreendemos a preocupação de Brahms com o descaso e a manipulação de conceitos, valores e práticas de cunho filosófico-científicos por parte de políticos oportunistas, marqueteiros e pessoas mal-intencionadas em geral. Contudo, no âmbito em que este ensaio se insere, acreditamos que não seja necessário haver o mesmo nível de temor demonstrado pela autora em relação às versões concorrentes da teoria da verdade nem com a tese da subdeterminação. Interpretações para lidar com ambos os temas podem ser encontradas em manuais de divulgação filosófico-científica, especialmente dentro das discussões sobre realismo e antirrealismo (DUTRA, 2003; FRENCH, 2009; JOHANSSON, 2016; DUARTE; HADDAD; GUITARRARI, 2016; MOULINES, 2020). O tratamento, por exemplo, das teorias físicas à luz da filosofia, da história e da sociologia da ciência tornaria a abordagem dos problemas metafísicos, epistemológicos e axiológicos sobre a verdade na atividade científica mais organizadas, claras e precisas.

Embora seja extenso, o nosso trabalho está longe de esgotar as complexidades do tema. Contudo, procuramos extrair do exame de fontes e de nossos comentários algumas ponderações e sugestões para a lida com a educação e a valorização da ciência diante do fenômeno da pós-verdade. Destacamos que a principal implicação para o ensino de ciências seja algo anterior à exposição dos conteúdos específicos de qualquer ramo científico. A partir da definição padrão, enfatizamos os aspectos emocionais, psicológicos e cognitivos relativos à credulidade, à quase irrelevância da verdade diante de nossas crenças e opiniões preferidas e ao peso da influência dos vieses cognitivos sobre decisões, atitudes e comportamentos. Para nós, é primordial que estejamos atentos aos nossos vieses cognitivos e aos dos estudantes. Convém dispensar algumas horas de aula para apresentar os mais comuns, bem como suas relações com falácias lógicas e heurísticas. A nossa preocupação também se dirige aos estados cognitivos (MURCHO, 2005) de professores e estudantes nas relações dialógicas qualificadas em sala de aula e além. Esses tópicos são igualmente fecundos para se tratar da relação entre conhecimento científico e política.

Por sua vez, a definição ampliada elaborada a partir da "filosofia da pós-verdade" de Yael Brahms nos auxilia a esclarecer os fatores envolvidos nas características e na aparência de novidade do fenômeno da pós-verdade. Pode-se constatar que a definição é mais rica e complexa. A implicação dessa reelaboração da definição está, em especial, na consideração do conceito de "verdade" tal como é abordado na filosofia em geral, bem como, especificamente, na filosofia da ciência, tanto em suas vertentes pós-modernas, quanto nas correntes mais, digamos assim, "ortodoxas".

Mui nos beneficiaria (em todos os aspectos, especialmente políticos e cívicos) ao estimular nos alunos um senso de respeito e propósito em relação aos hábitos de pensamento e de investigação filosófico-científica, bem como ao encaminhar a promoção e o cultivo de valores ligados à responsabilidade enquanto agentes cognitivos. Acompanhando Harari, apesar dos desconfortos emocionais e psíquicos, acreditamos ser "responsabilidade de todos nós investir tempo e esforço para expor nossos vieses e preconceitos, e para verificar nossas fontes de informação" (HARARI, 2018, p.301). Precisamos investir esforços para dar aos alunos e ao público em geral as condições de cumprirem tal responsabilidade sem dogmatismo, ceticismo ingênuo e leviandade, a fim de que possamos ser capazes de "clarificar a realidade a fim de entendê-la e agir sobre ela". 
Decerto, a história e a sociologia da ciência, dentre outros campos de investigação dedicados aos estudos de ciência, também estão mobilizadas. A perspectiva multidisciplinar que exaltamos e almejamos permite tais apreciações e reflexões mais amplas e diversificadas, sem que haja os mesmos ruídos e "falatórios" desorganizados (a verdadeira balbúrdia) e suspeitos das práticas e dos interesses que concederam ao fenômeno da pós-verdade a sua péssima fama.

\section{Referências Bibliográficas}

ARENDT, H. Verdade e Política. In: Entre o passado e o futuro. 8. ed. Tradução: Mauro W. Barbosa. São Paulo: Editora Perspectiva, 1972, pp. 282-325.

BRAGA, Miguel. Quando a ignorância gera confiança (o efeito Dunning-Kruger). Disponível em: http://blog.mi- guelbraga.net/quando-a-ignorancia-gera-confianca-o-efeito-dunning-kruger. Acessado em: 02/01/2014.

BRAHMS, Y. Philosophy of Post-Truth. The Institute for National Security Studies, 2019. Disponível em: <https://www. inss.org.il/publication/philosophy-of-post-truth/> Acesso em 22 jan. 2020.

BERNAYS, E. Propaganda. 1929. <http://whale.to/b/bernays.pdf $>$ Acesso em 13 de abril de 2019

BUCCI, E. Pós-política e corrosão da verdade. Revista USP. São Paulo. n. 116, p. 19-30 janeiro/fevereiro/março 2018. $<$ http://www.revistas.usp.br/revusp/article/view/146574> Acesso em 12 mar. 2020.

. Existe democracia sem verdade factual. Barueri, São Paulo: 2019. 135p.

CLIFFORD, William K.. The Ethics of Belief. Lectures and Essays. v.2. Londres: The MacMillan Company, 1879, pp. 177-211.

D’ANCONA, M. Pós-verdade: a nova guerra contra os fatos em tempos de fake news. Tradução: Carlos Szlak. Barueri: Faro Editorial, 2018, 142p.

DENNET, D. Daniel Dennett: 'I begrudge every hour I have to spend worrying about politics'. The Guardian: The Observer, United Kingdom. 12 fev. 2017. Disponível em: $<$ https://www.theguardian.com/science/2017/feb/12/daniel-dennett-politics-bacteria-bach-back-dawkins-trump-interview/>. Entrevista concedida a Carole Cadwallad. Acesso em 27 fev. 2020.

DIETHELM, P.; MCKEE, M. Denialism: what is it and how should scientists respond? European Journal of Public Health, Volume 19, Issue 1, Jan. 2009, P. 2-4, https://doi.org/10.1093/eurpub/ckn139 Acesso em 04 de maio de 2020.

DUARTE, A.B.; HADDAD, A.B.; GUITARRARI, R. (Org.) Realismos Antirrealismo. Seropédica, RJ: Editora do Ppgfil - Ufrrj, 2016, 156p.

DUNNING, D. We are all confident idiots. Pacific Standart: The Science of Society. Outubro 2014. Disponível em: $<$ https://psmag.com/social-justice/confident-idiots-92793/>. Acesso em 03 jan. 2015.

DUTRA, L.H.de A. Introdução à teoria da ciência. 2a. Edição. Florianópolis, SC: Editora da UFSC, 2003, 150p.

EMPOLI, G.D. Os engenheiros do caos. Tradução: Arnaldo Bloch. 1. Ed.; 1. Reimp. São Paulo: Vestígio, 2020, 192p.

FRANKFURT, H. Sobre falar merda. Tradução: Ricardo Gomes Quintana. Rio de janeiro, RJ: Editora Intrínseca, 2005, 72p.

FEYERABEND, P. A Ciência em uma sociedade livre. Tradução: Vera Joscelyne. São Paulo: Editora Unesp, 2011. 288 p.

FRENCH, S. Ciência: conceitos-chave em filosofia. Tradução: André Klaudat. Porto Alegre, RS: Artmed, 2009. 156p.

FULLER, S. O Intelectual. Tradução: Maria da Silveira Lobo. Rio de Janeiro: Relume Dumará, 2006. 159 p.

GENESINI, S. A pós-verdade é uma notícia falsa. Revista USP, São Paulo, n. 116, mar 2018. Disponível em: $<\underline{\text { https:// }}$ doi.org/10.11606/issn.2316-9036.v0i116p45-58/>. Acesso em 12 mar. 2020.

HARARI, Y.N. 21 lições para o século 21. Tradução: Paulo Geiger. São Paulo: Companhia das Letras, 2018. 441 p.

HUANG, S. When peers are not peers and don't know it: the Dunning-Kruger effect and self-fulfilling prophecy in peer-review. Bioessays, Medford, v. 35, 2013. Pp. 414-416. Disponível em: < https://doi.org/10.1002/bies.201200182/>. Acesso em 10 fev. 2020.

KAHNEMAN, D. Rápido e Devagar: Duas formas de pensar. Rio de Janeiro: Editora Objetiva, 2012. 608 p.

KEYES, R. Era da pós-verdade: desonestidade e enganação na vida contemporânea. Petrópolis: Editora Vozes, 2018. 310 p. 
KOYRÉ, A. Reflexiones sobre la mentira. Tradução: Hugo Savino. Buenos Aires: Leviatán, 2009. 80 p.

KRUGER, J.; DUNNING, D. Unskilled and unaware of it: how difficulties in recognizing one's own incompetence lead to inflated self-assessments. Journal of Personality and Social Psychology, Washington DC, v. 77, n. 6, jun. 1999. Pp. 121-134.

LATOUR, Bruno. Why Has Critique Run out of Steam? From Matters of Fact to Matters of Concern. Critical Inquiry, Chicago, Il, 30(2), 225-248. http://www.bruno-latour.fr/sites/default/files/89-CRITICAL-INQUIRY-GB.pdf Acesso em 03 de outubro de 2011.

LEVITIN, D.J. O guia contra as mentiras. Tradução: Leonardo Alves. Rio de Janeiro: Editora Objetiva: 2019. 325 p.

MANJOO, F. Learning to live in a post-fact society. Nova Jersey: John Wiley \& Sons, Inc., 2008, capítulo 4, pp. $94-141$.

MCINTYRE, L. Post-truth. Cambridge, Massachusetts Institute of Technology: MIT Press, 2018. Versão Kindle. Paginação Irregular.

MCRANEY, D. Você não é tão esperto quanto pensa. Tradução: Marcelo Barbão. São Paulo: Editora Leya, 2012. 252 p.

MCRANEY, D. You are now less dumb. Nova Iorque: Gotham Books, 2013. 309 p.

MENDONÇA, A.L.O.; ARAÚJO, P.; VIDEIRA, A.A.P. Primazia da democracia e autonomia da ciência: o pensamento de Feyerabend no contexto dos Science Studies. Filosofia Unisinos, São Leopoldo, v. 11, n. 1, abr. 2010. Pp. 44-61. Disponível em: $\leq$ https://doi.org/10.4013/fsu.2010.111.04/>. Acesso em 4 maio 2020.

MENDONÇA, A.L.de O. Filosofia da Ciência e science studies: a guerra pela paz. In: VIDEIRA, A.A.P. Perspectivas contemporâneas em filosofia da ciência. Rio de Janeiro: EdUERJ, 2012, p.165-184.

MIGUEL, L.R. Conservar e amar o básico: um relato sobre a "inutilidade" fundamental da universidade. Revista Em Construção. Rio de Janeiro, RJ. ano 1 n. 2, dezembro, 2017, p. 270- 298. DOI: 10.12957/emconstrucao.2017.31843< $\underline{\text { ht- }}$ tps://www.e-publicacoes.uerj.br/index.php/emconstrucao/article/view/31843>

MOULINES, Carlos U. O desenvolvimento moderno da filosofia da ciência (1890-2000). Tradução: Cláudio Abreu. São Paulo: Associação Filosófica Scientiae Studia, 2020, 272p.

MURCHO, D. Epistemologia da Argumentação. Pensar outra vez: Filosofia, Valor e Verdade. Vila Nova de Famalicão, Pt, 2005, Cap.7, pp. 93-108.

NICHOLS, T. The death of expertise: the campaign adainst established knowledge and why it matters. Nova Iorque: Oxford University Press, 2017. 273 p.

ORWELL, G. Política e a língua inglesa. In: Por que escrevo e outros ensaios. Tradução: Desidério Murcho. Lisboa: Ed. Antígona, 2008.

PHILLIPS, T. Truth: a brief history of total bullsh^t. Londres: Wildfire, 2019. Versão Kindle.

QUINE, W.V.O.; ULLIAN, J.S. The web of belief. 2a. Edição. Nova Iorque: McGraw-Hill, Inc., 1978, 148p.

ROBERTS, D. Post-truth politics. GRIST. 1 abril 2010. Disponível em: < https://grist.org/article/2010-03-30-post-truth-politics/>. Acesso em 10 maio 2020.

SANTAELLA, L. A pós-verdade é verdadeira ou falsa? Barueri: Estação das Letras e Cores, 2019. 98 p.

SANTANA, C.C.; MARQUES, M.F.O.; PINHO, M.J.S. A Educação Científica em Tempos de Pós-verdade. In: CHATES, T.J. (org.). Perspectivas Educacionais em tempo de Pós-verdade. Jundiaí: Paco Editorial, 2017. Cap. 5, p. 87-102.

SMITH, B.H. Crença e resistência. Tradução: Maria Elisa Marchini Sayeg. São Paulo: Editora Unesp, 2002. 302 p.

TESICH, S. A government of lies. The Free Library. 1992. Disponível em: < $\underline{\text { https://www.thefreelibrary.com/A+govern- }}$ ment+of+lies.-a011665982/>. Acesso em 4 jun. 2020.

VIDEIRA, A.A.P. A Filosofia da Ciência sob o signo dos Science Studies. Abstracta., v.2, 2005. Pp. 70-83. Disponível em: <http://abstracta.oa.hhu.de/index.php/abstracta/article/view/25/>. Acesso em 2 ago. 2019.

WANG, A. 'Post-truth' named 2016 word of the year by Oxford Dictionaries. The Washington Post. 16 nov. 2016. Disponível em: < https://www.washingtonpost.com/news/the-fix/wp/2016/11/16/post-truth-named-2016-word-of-theyear-by-oxford-dictionaries/>. Acesso em 4 de maio de 2020.

WRIGHT, J. "Many People Are Saying...”: applying the lessons of naïve skepticism to the fight against fake news and other "Total Bullshit". Postdigital Science and Education, v. 2, p. 113-131, jun 2019. Disponível em: <https://doi. org/10.1007/s42438-019-00051-0> Acesso em 15 maio 2020. 